\title{
Macrophage Inflammatory Protein 1 Alpha Measurement
}

National Cancer Institute

\section{Source}

National Cancer Institute. Macrophage Inflammatory Protein 1 Alpha Measurement. NCI Thesaurus. Code C82023.

The determination of the amount of macrophage inflammatory protein 1 alpha present in a sample. 